\title{
27. Between Eagles and Flying Foxes: Elections for the Manus Provincial and Open Seats
}

\author{
Steffen Dalsgaard ${ }^{1}$
}

People in Manus often speak in metaphors or in tropes (Tokpisin: tok piksa), particularly when referring to the politics of traditional ceremonies at the village level and in wider provincial forums. One of the prevailing metaphors of the 2007 election was that of the 'flying fox' (blak bokis); this was most eloquently expressed in a speech by Dr Gabriel Kulwaum, one of the candidates for the Manus Open seat. The flying fox is a migratory fruit-eating bat. It comes when the fruits are ripe and leaves when it has eaten them. In contrast to this animal is the eagle (tarangau). In the context of the election the eagle represented the true leader, who does not migrate but stays and looks after its territory. When potential voters were asked what kind of leadership qualities they were looking for in a candidate, most people said, 'looking after others' (lukautim ol), that is, being generous and helping others when they are in need.

In 2007, seven candidates contested the Manus Provincial seat, while 25 nominated for the Manus Open. Several of them had tried their luck before, but many were newcomers to politics, returned to Manus from influential positions in the urban centres of Papua New Guinea. The main contenders for the Provincial seat were expected to be the incumbent, Dr Jacob Jumogot, the previous governor, Stephen Pokawin, and the Lorengau mayor, Michael Sapau. The Open seat literally seemed more open with the large number of candidates, but former member of parliament (MP) Memel Pohei and a former Lorengau mayor, Job Pomat, were the names most frequently mentioned. As usual, the Manus seats were the first ones to be declared. This happened on 14 and 15 July respectively, when Michael Sapau and Job Pomat came out victorious.

\footnotetext{
1 I thank the people in Manus and the candidates, the Papua New Guinea Electoral Commission office in Manus and the provincial administration, whose assistance was invaluable. I am also indebted to the Institute of PNG Studies and the National Research Institute in Port Moresby. The paper has benefited from comments by colleagues in the Department of Anthropology, University of Aarhus, participants in Asia-Pacific Week 2008 at The Australian National University, and the State, Society and Governance in Melanesia Program at The Australian National University. I also thank two of my supervisors, Ton Otto and Mark Mosko. The research was made possible by grants from Denmark, namely the Faculty of Arts at the University of Aarhus, Bikuben Fonden, Carlsbergs Mindelegat for Brygger J.C. Jacobsen, and an EliteResearch travel stipend provided by the Danish Ministry for Science, Technology and Innovation.
} 


\section{Political and historical background}

Manus is the smallest province in Papua New Guinea both in terms of land mass (less than 2000 square kilometres) and population (approximately 52,000 people $^{2}$ that can be divided into roughly 30 ethnic or linguistic groups). ${ }^{3}$

Manus provides two electorates for the national parliament: Manus Provincial and Manus Open. (Manus is unique in that its Provincial electorate coincides geographically with its one Open electorate.) Administratively, this means that the provincial administration also functions as a district administration, and the province has been allocated a proportionately larger number of local-level governments (LLGs) than the other provinces - one urban LLG (Lorengau) and 11 rural LLGs (Figure 27.1).

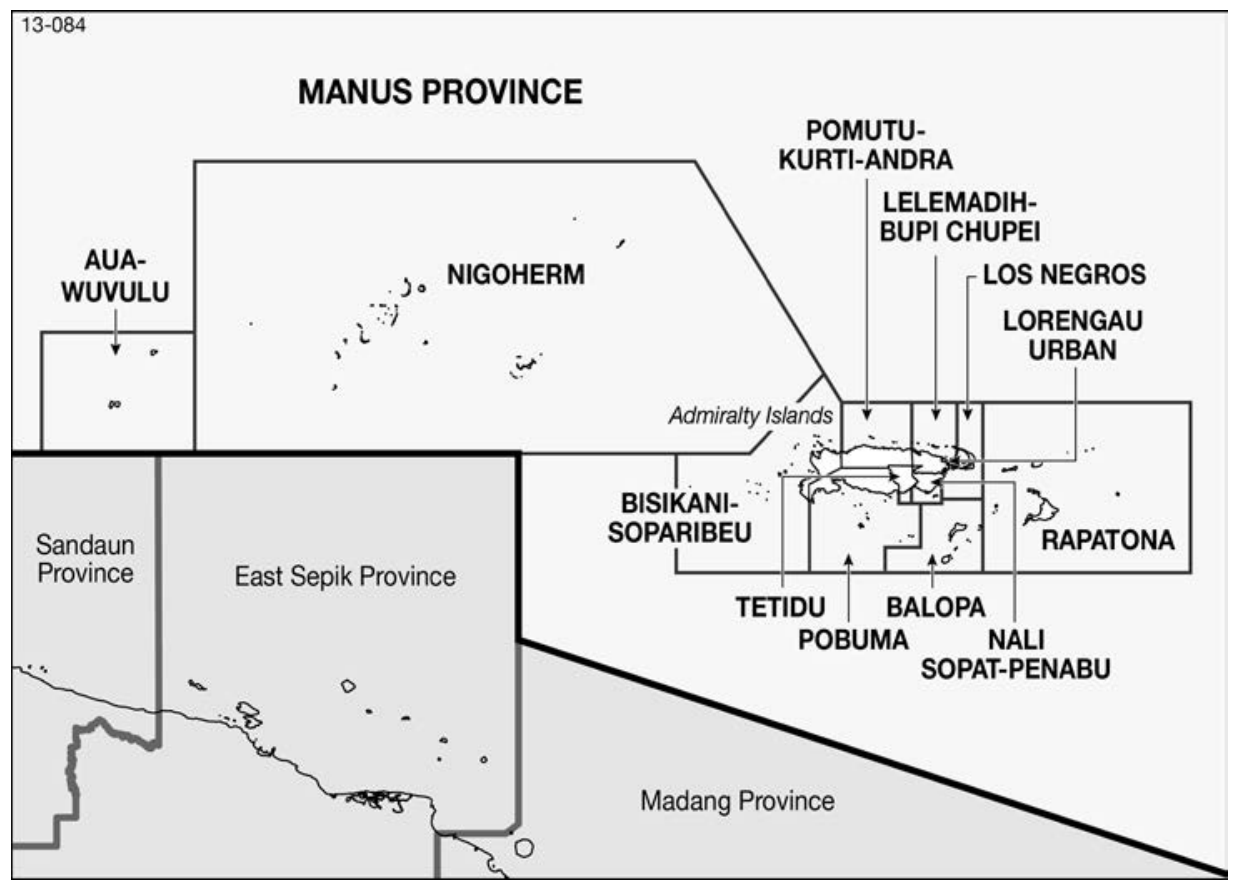

Figure 27.1: Manus Province and local-level governments

2 The 2000 census figure was 43,387. Projection of the 1980-2000 growth rate of about 2.6 percent per year gives 52,000 .

3 There has been argument as to the number of groups and languages, which depends on which definition one decides to use (Carrier and Carrier 1989:34). One of the latest (local) publications states the number as 30 (Minol 2000). For the purpose of this presentation I presume the different Manus groups to be quite similar in terms of political concerns and I distinguish between groups only when referring to specific practices. For a discussion of similarities and differences between Manus groups see Schwartz $(1963,1995)$, who argues in favour of regarding Manus as one 'areal culture'. 
Along with the other parts of what is today the New Guinea Islands Region, Manus was colonized relatively early, first by the Germans and later by the Australians. People in Manus went to the polls for the first time in 1964, when the National Assembly was established. Since then, one can discern two notable political features in national elections in Manus, which people referred to often during the course of the 2007 election. First, in every election there are people of Manus descent or people born in Manus, who have lived for a prolonged period outside of the province but return to contest the election without spending enough time to be reacquainted with the state of affairs in the province. These returnees had never been successful in contesting until 2002, where Dr Jacob Jumogot returned and defeated the incumbent provincial member and governor, Stephen Pokawin. Several well-educated emigrants seemed to have been inspired by Jumogot's win and to have judged that Manus people were now ready to vote for a returnee. Hence the popular reference to the metaphor of the flying foxes. The second feature is that Manus people have never re-elected a person once he or she has lost his/her seat, though every recent election has seen one or more attempting a comeback.

The metaphor of flying foxes also relates to the economy of Manus. Local sources of income have dwindled over the years, in part due to a devaluation of the Papua New Guinea kina, and neither copra, cocoa nor vanilla has provided the continuous returns that were originally hoped for. The most substantial economic activities in Manus today are logging, which is mostly based on the west coast, and bêche-de-mer harvesting, which is seasonal but in season is a bonanza for good divers. However, even though these enterprises have provided cash to villagers, they have not been enough to sustain people without supplementary access to subsistence foods (gardening or fishing). The financial capacity of the Manus provincial government is severely limited too, and tangible developments are rare. Several Manus groups therefore rely on remittances from wage-earning kin in other provinces to achieve material improvement of their lives. This funds a large part of consumption in Manus. Money from remittances is distributed in traditional exchange ceremonies (cf. Carrier and Carrier 1989), and often covers expenses such as school fees. Expensive acquisitions such as boats, motors or housing materials are rarely purchased directly from Manus, because only a few people in the province make enough money to obtain such goods.

\section{Prologue to the election}

Speculation about who would be candidates was abundant already a year before the election. A group of Manus people with access to the Internet discussed the issue vehemently in a forum on the web (www.pngscape.net.pg). Everyone was of course curious about whom they would be able to vote for, and in the 
provincial capital of Lorengau one heard rumours every now and then of yet another person who had told someone that he or she would contest the election. These rumours and speculation were by no means coincidental. The candidates themselves needed to test their chances beforehand by examining their support without promising too much. Several candidates considered the response of their kin and close associates in particular to be crucial. Their close relations were the ones who were expected not only to vote for the candidate, but also the ones who would carry the campaign to their relations.

As part of these preliminary manoeuvres, some candidates tried more or less discretely to influence voters on different occasions when they had a chance to speak or act in public. Those who had left Manus to live and work elsewhere but intended to return to become candidates could every now and then be spotted at the market in Lorengau making themselves publicly visible. Others tried to deter rival candidates from contesting the election by convincing them, either directly or via mutual kin, to step down, or by spreading rumours to create cleavages between possible candidates and politically influential people who were known to be allies. Some potential candidates did step down, possibly because their chances of exercising political influence would be greater if they threw their support behind others. Several of those who had themselves been candidates in the 2002 election were thus seen as key supporters of new candidates in 2007.

\section{The Open seat}

Inspiration from Jumogot's victory as a returning migrant was not the only source of inspiration for the first-time candidates. There was much speculation that the Open seat would be up for grabs since the incumbent MP, Charlie Benjamin, was rumoured to be intending to challenge Jumogot for the Provincial seat. But six months before the election, Benjamin was found guilty by a Leadership Tribunal of having violated the Leadership Code. He was dismissed from parliament and banned from contesting elections for three years. The Open seat was thus vacant and drew 25 candidates. Two of these were women. Six had previously contested a national election. More than half of the 25 normally resided outside Manus or had recently been retrenched and moved back to their native village. Most of the candidates (including those for the Provincial seat) were well educated and had made significant achievements in their fields. Several gave up well-paid jobs to contest the election; an article in the Post-Courier's election special referred to the elections in Manus as 'the battle of the brains' (Post-Courier, Election Special June 2007). 
The contest for the Open seat saw a significant increase in candidates compared to recent elections. ${ }^{4}$ Among the major contenders were the runners-up in the previous two elections (Job Pomat and Memel Pohei), but a couple of first-time candidates were given good chances because of their educational backgrounds and successful careers; these included Ted Sitapai, former secretary of the Department of Agriculture, and Les Roai, who had worked as a college administrator in Lae. Roai was the first serious candidate in a national election from the remote western islands. However, with the large number of candidates and the new limited preferential voting (LPV) system, many saw it as anyone's game, and there was much speculation about what would be determining factors. Most LLGs had several candidates, and it was inevitable that most candidates' base votes would be divided. The Balopa LLG had the most candidates (six) relative to its population (1342 enrolled voters), with many close relatives contesting. The north coast of Manus Island was also well represented (four candidates) as was the west coast (six), but both of these areas had larger numbers of enrolled voters.

\section{The Provincial seat}

I have noted that Manus people have never re-elected a person who has lost his/ her seat. Stephen Pokawin was aware of this historical fact when he decided to challenge Jumogot, and even said during his campaign that he would see if he could be the first one to regain a Manus seat. Memel Pohei, who had contested every election since he was an MP in 1992-93, always finishing second or third, tried for the Open seat again in 2007. Another heavyweight contestant for the Provincial seat was the mayor of Lorengau and deputy governor Michael Sapau. Sapau had severely criticized the incumbent governor with whom he had had strong disagreements in the (provincial) Lapan Assembly, where he was a member as the mayor of Lorengau. He was expected to perform well because he was believed to have the support of the Catholic community, which is the largest religious denomination in Manus. Lawyer Ben Lomai, Dr Peter Sapak (a University of Papua New Guinea lecturer), Leslie Menei and Keliwin Sasa were the other four contenders. Generally, people expected the contest to be between Jumogot, Pokawin and Sapau, with Lomai and perhaps Menei as dark horses - Lomai because he was deemed to be wealthy enough to run a comprehensive campaign, and Menei because he had finished third in the 2002 election. However, since Lomai and Sapak came from the same area in Manus, their base vote would be split, and Menei's previous election promises had since been undermined by accusations that they were 'cargo cultist', because

4 In 2002, 12 candidates; in 1997, 15. For numbers of candidates in elections prior to 1997 see Pokawin and Rooney (1996:127). 
he promised social services such as unemployment benefits. The contest for the Provincial seat thus saw a decrease in the number of candidates compared to recent elections, undoubtedly because many perceived Jumogot, Pokawin and Sapau to be very difficult to beat. Sapau, Lomai and Sapak were contesting national elections for the first time.

The characterization of the Open seat as a contest among educated 'flying foxes' applied also to the Provincial seat; only Sapau and Sasa had been living in Manus for a long period up to the election. Even the governor and Provincial member, Jumogot, had been criticized for often being away in Port Moresby rather than being close to people in Manus, listening to their requests and attending to their needs. Jumogot defended himself by saying that only in Port Moresby could he do what he was supposed to do, which was to attract resources that could develop Manus. He had criticized his predecessor Pokawin for being too much in Manus and not doing anything. After the 2002 election Pokawin had disputed the result because Jumogot allegedly had used his position as head of the Papua New Guinea Gaming Board to distribute money and thus 'buy' votes, but the case was dismissed because of lack of evidence. After losing to Jumogot, Pokawin too had been away from Manus - most of the time as general secretary of the National Alliance or as adviser to Prime Minister Sir Michael Somare.

The period from 2002 to 2007 had seen some notable physical developments in Manus. In return for letting Australia run the detention centre for asylum seekers in Lombrum, the Australian Agency for International Development had provided upgrades of some of the schools in the Los Negros LLG, from whence Jumogot came. The upgrading was carried out while Jumogot was governor, but the deal had been set in place under Pokawin.

What came to be one of the most important issues in the election campaigns of both Jumogot and Pokawin was the issue of the Manus Highway. The highway is a gravel road that runs from Lorengau inland connecting the villages of the interior of Manus Island with the provincial capital. For 20 years the road had been potholed and difficult to navigate without four-wheel drive, especially in wet conditions. However, while Pokawin was still governor the World Bank had agreed to finance reconstruction of the road against 10 percent counterpart funding by the government. No work was carried out before Jumogot became governor, though, and now they both strove to take credit for the reconstruction. Some saw the reconstruction as evidence of the delivery of government services while others, especially those without relations inland, questioned why such a large sum should be spent on the road: it would only help inland people, who were few in number compared to the coastal or island dwellers in the province, and 10 percent of the total cost was still a large proportion of the total funding available to a province with a small budget. Pokawin's campaign in the area covered by the highway may have been boosted by alliance with Pohei, who 
came from the inland of Manus and was endorsed by the National Alliance, and it probably benefitted from a visit by Sir Michael Somare, who spoke to people in the village of Tingou and promised a donation to the local health centre. Jumogot located a part of his campaign launching in nearby Kawaliap, where he had several supporters. Former prime minister and leader of the People's Democratic Movement, Paias Wingti, was supposed to attend, but could not. Nevertheless, the Kawaliap people decorated Jumogot with symbols of traditional leadership, and string bands from the area created songs to honour him (including one about voting for 'white gravel', referring to the road reconstruction, which used gravel from the Los Negros LLG). This concern for demonstrating one's achievements in office was not confined to the Provincial seat. Prior to being indicted, Charlie Benjamin had bought cars for the police and the hospital with the District Support Grant at his disposal. Both of these cars carried writing on the side stating that they were 'donated by Hon. Charlie Benjamin MP member for Manus'. Prior to being convicted, Benjamin was regarded by people I spoke to in Lorengau as a good leader, for which the cars were seen as evidence.

\section{The role of parties in Manus}

Prior to the election, several candidates could be seen 'shopping around' for party endorsement. To most, this was a matter of obtaining funding to run a campaign. Rumour had it that some of the candidates expected to put this funding in their own pocket and campaign simply by talking to people at the smaller markets in Lorengau. But there were also a few faithful, who had been long-time members of their respective parties, such as Pokawin for National Alliance and Jumogot for People's Democratic Movement. Also, Ronny Knight had joined the New Generation Party for its cause rather than opportunism.

Party affiliation was not very important in peoples' voting. Only one person I talked with said that he had given one of his preferences to Ronny Knight, because he liked the New Generation Party. Otherwise I did not hear much mention of party preference. The party with the best organized campaign in Manus was the National Alliance. The two candidates appeared on a poster together, and Sir Michael Somare came to Manus to endorse them at events in Lorengau and Tingou; generally they tried to give the appearance of loyal cooperation. The other party which fielded candidates supporting each other was the New Generation Party. Bart Philemon came to endorse them and gave a speech at the Lorengau market and in two villages close to Lorengau, which seemed to impress a lot of people. Several people told me that if Philemon had contested in Manus they would have voted for him, but they were not so sure 
about his candidates in Manus. People's Progress Party and People's Action Party also had candidates for each seat in Manus, but they did not seem to campaign together.

\section{Launchings and nominations}

An important part of many of the candidates' efforts were events surrounding the launching of their campaign and nomination.

Several candidates hosted large-scale launching feasts where relations (extended kin, colleagues, etc.) and neighbouring villages were invited. All participating groups brought some food as a contribution, but were also fed by the candidateeither with pork or sea turtles, which are the ceremonial meats. Groups were also given food and typically betel nuts to take home. During the launching event, invited speakers of standing would praise the candidate - his qualities as a leader, his knowledge, his experience and how they knew him. ${ }^{5}$ The candidate would also speak, mostly trying to be humble but also presenting some of his visions. In between the speeches, traditional dancers, string bands or choirs would entertain, the latter with songs written about the candidate to honour or praise him. These launching feasts did not resemble any traditional type of feasts in particular, but they included several elements that could be classified as strongly traditional, such as the way food was distributed. Additionally, in some cases, the event involved the cutting of a rope of betel nuts and distributing the branches - one to each participating group as a way to urge them to support the candidate. In the past, such distributions of betel nuts were seen as acts of compulsion - whoever accepted a rope of betel nut indicated that he would support the donor. Ton Otto (1992b: 275-76) has described how this was an issue of contention in 1987, since many thought that the 'ways of government' should be kept separate from the 'ways of custom'. In 2007 I witnessed no such disputes. Because of the LPV system, some people actually argued that it was all right to accept betel nuts from more than one candidate, since there were three preferences to be given. These three preferences were in fact mostly seen as three votes in their own right. One man even told me, 'A little bit of government, a little bit of tradition (kastam), that is all right'.

Organizing such a feast requires large resources - usually in terms of both money and a network of kin and allies who are willing to come and give support with their presence and contributions. In that regard it is comparable to the demands of traditional ceremonies (wok kastam), which in many places is the hallmark of the traditional (entrepreneurial) leadership (see Schwartz 1963; Otto 1991).

5 I did not witness either of the two women candidates host such an event. 
Likewise, during the nomination period, almost half of the candidates came to the Papua New Guinea Electoral Commission's office in Lorengau, not just with a procession of supporters, but also wearing at least some kind of traditional decoration. A couple of candidates wore 'crowns' made with shells or dog teeth, while others were followed by several hundred people carrying adornments symbolizing traditional leadership and cultural artifacts important in traditional ceremonies. Some were accompanied by a log-drum (garamut) ensemble on the back of a truck with a troupe of dancers escorting the candidate to the door. Some of the nomination processions displayed significant parallels to processions involved in traditional ceremonies, brideprice in particular.

All this testified to the importance of references to traditional culture, which have become increasingly visible in provincial politics over the years. On the one hand, such references can be seen in the naming of the provincial assembly, Lapan Assembly (referring to traditional leaders), in the drafting of legislation that attempts to protect traditional culture (Dalsgaard 2007), and in introducing traditional leaders as chiefs into the legislature (see Otto 2002). The latter reflects expectations of good leadership. On the other hand, such references relate to the significance of kastam (tradition or custom), with its plethora of meanings from mortuary rituals and ceremonies relating to marriages or births to a general set of values and institutions that one should follow to be successful and to live up to correct ethical and moral standards, or even to a domain of kalsa (culture) that seems to change in its emphasis on traditional practices according to a global culture of performative practices (see Dalsgaard and Otto forthcoming).

Of the candidates for the Open seat, Albert Punjimill was the paramount chief for the Nauna people, but while being a traditional leader commands respect, leadership rarely carries weight outside one's group or territory, and I did not meet anyone who voted for Punjimill because of his title. Other candidates, too, claimed to be from lapan lineages, but it is unclear whether this affected voters' choices, though to command the vote in a specific village it was important to be on good terms with, or at least acknowledge, the local leaders, who were expected to be able to carry votes.

\section{Strategies of campaigning and voting}

Campaigning for both seats was done in numerous ways. References to tradition and the ambiguous relationship between emigrants and those who stayed at home in the villages were two central discourses influencing the way candidates presented themselves as potential leaders. These strategies have been alluded to above, and will be referred to again in explanations of why people voted as they did. 
The candidates I interviewed said that they depended on their kin to carry their campaigns, but using former or present colleagues or even old school mates was also seen as a way to mobilize support. Most candidates had a campaign coordinator. Some had a couple of regional coordinators too-for instance, one for central Manus, one for the west coast, and so on. Some of the most serious candidates had even more elaborate systems, including a campaign komiti for each LLG or even each village in the areas where they were strong. The task of these komiti was to estimate the amount of votes the candidate could expect in the local area, provide a place to stay if the candidate came on a visit, and arrange for the candidate to deliver a speech or hold a campaign meeting in the local community.

Even if they did not have a komiti, most candidates had contacts in all LLGs around Manus, and used these contacts to introduce them on the campaign trail. However, some voters told me that this did not always give the best impression: they were afraid that if a particular candidate won, only the local contacts(s) would benefit. Visiting a village through one's relatives, rather than openly as a candidate who would represent everyone, was seen as having a negative and clandestine aspect. Local disputes were very decisive in voters' impressions of a candidate, and a candidate who was introduced by the wrong person could impair his/her chances rather than benefit from a local contact. Not all candidates travelled though the electorate, some because of limited funding. The western islands (Wuvulu, Aua, Nigoherm group) were far away, and some candidates reportedly travelled by speedboat together (Post-Courier 29 June 2007). The candidates who did not have the resources to travel mostly remained in Lorengau, counting on having a name that people throughout Manus already knew, or using radio advertisements. Others campaigned in selected areas where they knew they had support and counted on winning by mobilizing this base vote.

All candidates had produced some kind of poster, leaflet and/or business card that they handed out to their campaign coordinators for distribution to potential voters. Some candidates were severely hampered, however, because Air Niugini for several weeks in a row did not have space for extra cargo and some did not get their posters before the last week of campaigning.

When speaking to people, the candidates stressed a variety of issues depending on who they were, what they had done, and who they were speaking to. Those who had stayed away from Manus for longer periods emphasized what they had learned or accomplished while away. Jumogot simply listed everything he claimed to have done as governor-a list which was also reproduced on 
his campaign leaflet. ${ }^{6}$ Other candidates told people about their degrees, or tried to show that they were knowledgeable about the political system and the administration in Waigani. Moses Taian, for example, had been general secretary of Pangu and emphasized that Waigani too was a 'bush' that one had to know in order to find 'the food' that one needed. Peter Sindra responded to the flying fox accusations by asking who had paid for the corrugated iron roofs and the speedboats anchored at the coast. The flying fox left its droppings behind which could make things grow-in other words, Manus people who went abroad remitted money or goods to help their kin and home village, and their knowledge had effect. Some candidates felt an urgency to remind people that they were always there for those of their kin who needed help and that they were good at looking after others. Sometimes such praise for the candidate would be voiced by his or her campaign coordinator or another important person supporting the candidate. Most candidates also spoke about ideas they had for development, and how they thought Manus could be improved. A few used metaphors and symbolic expressions, but did not always get the message through.

However, claiming knowledge was not always enough. Those returnee candidates who had not put their knowledge to use by providing something for their kin or fellow villagers in Manus were regarded precisely as flying foxes. Knowledge is and has always been regarded as important in Manus (cf. Otto 1992a), but people who do not apply knowledge in practice can be seen as arrogant or even a nuisance. For example, a man who had spent three years trying to understand voting behaviour in Manus, and was the most educated of the contenders for the Provincial seat in 1992, found himself finishing last in that contest (Pokawin and Rooney 1996:140). One of the 2007 candidates, Lemen Polau, claimed to know about the functions of government, which he had learned as an LLG president and previous to that as an aide to the late Martin Thompson, former MP for Manus, but Polau also reflected a particular stance on leadership which I observed in Manus. He distinguished between a leader of knowledge (save) and a leader of heart. To him, the latter was preferred, and that was what he claimed to be. Generally, good leadership was referred to as having a 'heart' for people, and was sometimes associated with being a lapan. This kind of leader not only shared his wealth with others and 'carried their worries', but could also talk, eat and sleep with people - in other words, he did not distance himself from the grassroots person. To some, the discourse on good leadership contained references to God, and being a 'God-fearing leader'. Job Pomat was a devout

6 The leaflet claimed that he had attracted projects worth well over K500 million to Manus during his period in office, though adding together the value of each project he had listed, the amount did not even reach K100 million. 
Seventh-day Adventist; Luke Polongou referred to his faith as a member of the Evangelical Church; Peter Sindra had studied to become a Catholic priest; and Michael Sapau was known for his large donations to the Catholic Church.

Since intermarriages between groups of all kinds and levels (kin, village, ethnic, religious) are frequent in Manus, people usually have relatives that speak a different tokples, identify with a different ethnic group, or are members of a different religious denomination. Consequently, prediction of voting based, in particular, on ethnic affiliation or LLG is at best difficult; nevertheless it can give an indication of a possible outcome, and most candidates, campaign coordinators and potential voters tried to calculate the likely result accordingly. For candidates, it was also a means of estimating their own chances and deciding where to focus their campaigning. Most ethnic groups were divided over candidates, and religious divisions seem to have been of limited significance in the Open seat. Thus, Job Pomat received support from both the former member, Charlie Benjamin, and 2002 candidate, Poruan Sapulai. Pomat, Benjamin and Sapulai are from different parts of Manus, but are all Seventh-day Adventists, and Pomat contested as a candidate for the People's National Congress, of which Benjamin was a party member. Similarly, Michael Sapau seemed to rely on a Catholic vote.

As Wanek and Wormald have noted (1989:191), elections in Manus are seen by many as a mobilization of one's extended family and a struggle for those people 'in-between' who are related to several contestants. This was a dilemma for several candidates who were fairly close relatives (in two cases, cross-cousins), and this was seen as likely to reduce their chances. The point has been put by Pokawin and Rooney (1996:137) that a candidate, in order to be a serious contestant, must first secure his or her 'base vote' (as bilong basket or simply asbasket), that is, kin, people from one's village or LLG, and in some cases (such as Michael Sapau) one's religious community. In order to win, it is also necessary to get votes outside one's own area and possibly from across Manus.

Obtaining votes is about creating relations. In traditional exchange ceremonies people position themselves in relation to those who distribute by explaining how and through which common ancestors they are related. This is referred to as finding a 'road' through the kinship network. The same applies to electoral politics. If possible, a candidate will explain to people in a village how he/she is related to them, or will find a road by appealing to other identifications such as inhabiting the same local-level government area $^{7}$ or sharing church affiliation, or will have a friend or ally (a schoolmate or a colleague) explain to people how they knew the candidate, and thus create the link. The more formal part of

7 People in Manus have begun to identify with LLGs as political and administrative units, which also affects voting (see Pokawin and Rooney 1996:125-126). 
candidates' speeches focuses on their achievements and ideas for development, and perhaps criticizes rivals, depending on the standing of the rivals in the village. Most candidates quickly realized that cooperation with and praising of rivals was a more fruitful strategy than criticism. When visiting each others' strongholds, candidates often praised the perceived preferred choice of the people to whom they were speaking, and then humbly asked for the voters' second or third preferences. A few candidates failed to practise this, perhaps because they had not clearly understood the consequences of the LPV, or perhaps because they took their own popularity for granted, and that may have contributed to their downfall. Jumogot and his close supporters were convinced that they would win on the first count, and he was seen by some as arrogant and immodest, because he talked only about his achievements and did not show respect for his rivals. Pokawin, on the other hand, was good at giving credit to other candidates where he thought it was due, adjusting his speeches to the audience, and emphasizing the good qualities of some of his rivals - knowing that criticism could be seen as back-stabbing or mud-slinging, and could deter voters from giving him their second or third preferences. It was generally seen as good manners if a visiting candidate told a village that their preferred candidate (if they had one) was a good man, and that the visiting candidate respected that the first preferences of the village were already spoken for.

Campaigning in Lorengau was a bit different from campaigning in the villages because audiences comprised people from all over Manus - especially at the central market. Speeches at the central market were less targeted to a specific audience and more about giving a general impression. Not all candidates went there, perhaps because there was a fee of K100 to use the venue. A nongovernment organization, 'Manus Development Forum', ${ }^{8}$ invited all candidates to debate at the market one Friday afternoon. Six candidates from the two seats accepted the invitation, presented themselves, gave their opinions on an issue related to development, and answered people's questions.

The candidates that were expected to have the best chance for the Open seat were Pomat and Pohei; both had relatively large and unchallenged base votes. Several candidates tried to split each other's base votes, or at least get their second or third preferences, and there was a focus on the LLGs that did not field candidates - Los Negros in particular. The incumbent governor, Jumogot, was from Los Negros, and several candidates for the Open seat accepted his invitation to speak to his supporters. This led to speculation that some candidates were contesting either to help others (for example, a candidate for the Open seat who tried to align himself closely with the governor and always mentioned him in his speeches), or to ruin the chances of others. One might think that vote-

8 Manus Development Forum was founded in January 2007 and changed its name twice before the election, which caused some confusion about the aim of the group. 
splitting would be more difficult under the LPV system, perhaps needing three candidates to prevent a rival from getting the second or third preferences, but vote-splitting still seems to have occurred. Another strategy that could have come into play with the LPV system was 'vote-pulling': fielding a candidate who could pull in second preferences. Both vote-splitting and vote-pulling depend on voters supporting a specific person, and not only giving their first preference to their primary candidate but also following his or her advice on second and third preferences. It is uncertain how well that worked in Manus since the results showed that preferences were distributed among several candidates.

Finally 'giving' could be seen as an immensely important aspect of both campaigns and the impression of voters. This was evident in the discourse on flying foxes and the notion of reciprocity, and in relation to the Manus Highway, which was symbolic of government services. Typically, a good leader must be effective in attracting resources. Several candidates brought at least a rope of betel nut when they went to a village. In order not to abuse the hospitality of villagers, most travelling candidates brought food as well, or perhaps money in return for being allowed to stay overnight in the village. There were rumours of outright vote-buying, and of clans accepting money from candidates in exchange for promises of support, but it is difficult to determine the fine line between being generous and 'buying' votes, and difficult to say whether such behaviour affected the results. One candidate told me: 'Your campaign begins when you are born, and it is what you do throughout your life and what you give throughout your life that determines people's impression'. Transactions involving money must be seen in the context of demands for evidence of generosity, and such transactions are often part of long-term relationships. Generosity can be shown in many ways, such as giving feasts, feeding people, giving small sums to help people pay their school fees, or simply offering tea, scones, betel nut or other kinds of refreshment. Candidates and their supporters did their utmost to entice voters in this way until the very last minute. Particularly in Lorengau, a colourful landscape was created around the polling places by stalls representing several of the important candidates. Some candidates also used this as a way to conduct their own 'exit poll', observing which stalls voters visited. Some voters were 'educated' on how to vote by having someone write down the names of their preferred candidates on a slip of paper or on the palm of their hand.

\section{The electoral roll, the casting of ballots and potential irregularities}

Fraudulent practices, violence, and other election irregularities that have been noted especially in the Highlands - in particular in Southern Highlands 
Province in 2002 (see Gibbs, Haley and McLeod 2004) - are rare in Manus. One person admitted to me that she had voted in the name of another person because she was not enrolled herself. Another person (in a south coast village) was arrested by the police and gaoled for having done the same thing, when someone recognised him. There were reports of people voting more than once. The supporters of one of the candidates for the Provincial seat were said to have enrolled both in Lorengau and in their home village in order to vote twice, but I did not speak with anyone who admitted having done that. Multiple voting should be prevented by the application of indelible ink on the little fingers of those who had voted, but a persistent, though according to Ron May (personal communication) dubious, rumour has it that it is possible to wash the ink off with a lime.

The electoral roll generally appeared to live up to expectations. Skimming the roll for those villages where I knew people, I found examples of people enrolled twice under different names, though that did not mean that they voted twice. Some people complained that they had not voted because they were not on the roll, although they claimed to have enrolled. This was also reported by several polling officials. A total of 21,312 ballots were cast for each seat, in comparison with 23,380 voters enrolled, which does not seem unrealistic although a bit low in relation to the projected population of approximately 52,000 people if one assumes that 50 percent of the population is aged 18 and above.

Several polling teams reported that the plastic seals for the ballot boxes had been cut when they had travelled between polling places. Their explanation was that the padlocks on the ballot boxes were too heavy and the seals were broken as a result of the bumpy conditions of roads, and large waves encountered when travelling in speedboats. Since this happened to several polling teams, it is likely that the seals did indeed break in this way and that polling officials did not tamper with the ballots. ${ }^{9}$ Besides, there were mechanisms in place to account for all ballot papers, as each paper was numbered and the numbers noted when papers were put in the box at each polling place. If polling officials were to cheat, they would have had to do so as teams, which seems unlikely, since members of polling teams often supported rival candidates.

There was some suspicion of irregularities in the counting process, since the electoral officers at the counting tables for the Open seat included kin of the candidate who won that seat. However, the runner-up (Ronny Knight) did not pursue the case.

The number of informal votes suggests that the late decision to have a poster with candidate names, photos and numbers and a separate ballot paper, had a

9 Experience in other parts of the country reinforces this view. [RJM, ed.] 
significant impact, not so much because people had to write the numbers or names of their preferences, ${ }^{10}$ but because it was easy to mistake the two ballot papers and to write in the preferences for the Open seat on the ballot paper for the Provincial seat, and vice versa. In 2002 approximately 0.5 percent of the vote was informal (92 out of 18,780 for the Provincial and 97 out of 18,772 for the Open seat), and in 1997 between 0.6 percent and 1.1 percent (185 out 17,113 and 108 out of 17,115 respectively). In 2007 it exploded to 904 informal votes out of 21,312 (4.2 percent) for the Provincial and 677 out of 21,312 (3.2 percent) for the Open. This was even larger than in the first national election in 1964, when the percentage of informal votes in Manus was less than 1 percent (Hughes and van der Veur 1965:420). Only in the Aua/Wuvulu and Tetidu LLGs were the percentages fairly low (1.5 and 1.1 percent for Aua/Wuvulu and 1.3 and 0.9 percent for Tetidu). ${ }^{11}$ It could be that the awareness had been particularly effective in those areas, or that there had been less awareness in many of the other areas than the electoral officials claimed. The Ombudsman Commission, Transparency International and the Papua New Guinea Electoral Commission conducted an election awareness workshop in Lorengau but, apart from that, all awareness was carried out by the provincial electoral office, which mostly employed public servants from the provincial or the LLG administrations. From my interviews it was clear that several voters had difficulty understanding how the vote would be counted. Some people thought that if no one had a majority after the first count, the second preferences on all ballot papers would be counted, and so on; some even thought that they had three votes rather than three preferences. A man who was a member of the provincial assembly talked about his preferences as if he thought that when the candidate who received his second preference was eliminated that preference would count as an extra vote for the first preference candidate, who was still in the race. These perceptions had an impact on voting strategies, and would help explain why some voters wanted to get rid of their second and third preferences by giving them to candidates that they expected would be eliminated quickly. Even people with an understanding of the counting procedures persisted with this strategy, because they felt that giving even a second or third preference to a rival of their first preference candidate would be a threat to him. If their first preference candidate was eliminated, they could then not be said to be voting for someone else if their second or third preferences were out the race.

What worked well in Manus was the respect for privacy in the casting of votes. I did not see anyone (scrutineers, officials or other voters) try to observe how

10 Preferential voting had been used in Manus in the past when electing the premier and Manus has a high proportion of literate people by Papua New Guinea standards. Even if illiterate themselves, most people had someone who could help them, although I was asked twice by a polling official to assist a voter, since I was the only one who was deemed to be neutral by both the officials and the voters in question.

11 I do not have the number of informal votes for each LLG for the 1997 and 2002 elections, so I cannot conduct a detailed comparison. 
others voted except in those cases where illiterate people needed assistance. However, the secret ballot did create uncertainty in the exchange between voters and candidates. As mentioned above, eliciting votes from people was frequently attempted by traditional means of obliging support and reciprocity (feast-like campaign launchings, distributions of betel nut, etc.), but since the ballot was secret the candidate did not know for certain who voted for him or her, and the voter could not prove that he or she had cast a vote for a candidate as promised. Elsewhere, non-literate voters were happy to have the opportunity to bring along an assistant of their choice to the polling booth (Foster 1996:164165).

There was no real violence, but there were a couple of reports of threats. People who were strong supporters of Peter Sapak, a west coast candidate for the Provincial seat, said that Jumogot would not be allowed to campaign in their home area, after a fight over someone switching affiliation, but I did not hear about Jumogot changing his campaign schedule because of that. Some west coast people tried to evoke a 'west coast identity' in order to maintain a 'balanced Manus' with a seat in their area, now that Charlie Benjamin (originally from a west coast village) was out. One candidate was said to have threatened that if he did not win, others would force people off their land (implying that he was the only one who could protect them from being evicted). A riot squad of nonManusian police was present during the election, but they did not seem to be busy.

Another kind of 'violence' that some candidates feared was sorcery, and they employed different protective measures against it; others were reported to be using divination to predict when to go where. The most conspicuousalthough non-violent-incidents occurred after it became obvious that the incumbent Provincial member had not won. People from Loniu-Jumogot's village - attempted to block the road between Lorengau and Momote Airport with trees across the road (and also nails when Michael Sapau returned after being sworn into parliament). The police anticipated the trouble, however, and raced ahead of the convoy of government vehicles to remove the obstacles. Some Loniu people had also attempted such 'protests' after the 1997 election, when their candidate finished only third in the contest for the Open seat. This time the Loniu seemed to be so convinced that their candidate would successfully defend his seat that no one attempted to block the road until after the election, and then it was merely an expression of their disappointment. 


\section{Analysis of the results}

When the first preferences had been counted, it was clear that there was an overlap between the distribution of votes and categories of ethnic affiliation or residency. Candidates got the largest vote in their home area (LLG). Some voters said that their village should split their vote between the most promising candidates so that whoever won, the winner would be obliged to help them because they had voted for him or her. I am not sure whether that happened, but it adds perspective to the perception of reciprocity between political leaders and their constituencies. Generally, it was my impression that people voted for candidates to whom they had a relation, but not necessarily a kinsperson if that person was not generous or did not have a good reputation. There were examples of people choosing generous non-kin over non-generous kin against whom they had a grudge.

During the counting, it also became clear that both western islands and west coast people had bloc-voted for their local candidates in both seats. For the Open seat, a very large percentage on the western islands had chosen Les Roai; among the west coast people Ted Sitapai was the preferred choice. For the Provincial seat, most west coast people preferred Peter Sapak or Ben Lomai; when Sapak was excluded, most of the vote went to Lomai. Voting in other areas of Manus was more widely spread, in part due to the larger number of candidates.

In the Open seat, Roai, Knight and Pomat seem to have appealed to voters in most LLGs. Roai, Sitapai and Pohei received strong support in their own area, but it was not sufficient; Sitapai especially got little support outside his own area, and Roai's small base in the western islands was outweighed by Knight's general popularity and by Pomat's larger base vote from the more densely inhabited area of Lelemasih-Bupichupeu LLG. Pomat eventually secured the seat.

For the Provincial seat, Jumogot and Pokawin received approximately the same amount of votes as in the 2002 election, suggesting that their bases had remained largely intact, but Sapau proved to be a more popular candidate, drawing on a base in Lorengau and the Nali area as well as among Catholics throughout Manus. The battle between Jumogot and Pokawin for credit for the reconstruction of the Manus Highway does not seem to have moved many voters. Sapau received the most votes from the areas in the proximity of the highway.

Thus it was people who had stayed in Manus for a long period of time that won. Both winners had the support of their religious communities and as a Lorengau businessman (Sapau) and an important landowner in the vicinity of Lorengau (Pomat), they both had sustained relations to a large number of people. Through business and land one can gain a reputation for looking after others, either by providing employment or giving donations or simply letting people live 
on one's land. A few candidates accused of being flying foxes did well too, probably evidence of their ability to negotiate a relationship with villagers and live up to their expectations.

With regard to the impact of the LPV system, Ruth Mandrakamu was the only one to improve their relative position when preferences were allocated, jumping from 14th place after the first count to finish in 11th place-perhaps because some women did give her their second or third preferences. Some candidates made significant advances when someone from their own ethnic group, LLG or extended kin group was excluded, only to see other candidates follow suit when a candidate from their area was excluded. Judging from the first preference vote, LPV did not change the outcome significantly from what it would have been under first-past-the-post. Both winners, Pomat in the Open seat and Jugomot in the Provincial were leading on first preferences. People did not yet know how to use the system effectively; they tried to vote strategically for candidates they thought would win rather than candidates they would have liked to support. Afterwards, people were saying that they would have voted differently if they had known what the outcome would be.

The election showed that voters could relate to three candidates instead of just one. However, LPV voting is not just a matter of trade between a candidate and a voter, but also between candidates promising each other their supporters' second or third preferences as if these could be commanded by the candidates. It is not uncommon that people follow the 'advice' of traditional leaders, or in Lorengau their employers, on who to vote for. Some people wanted only one vote, and there were examples of people giving their second and third preferences to candidates considered certain losers. There was also confusion about how the counting would be done, which informed the way some people voted: some thought that all preferences would be counted-even on the ballots whose first preferences had not yet been excluded.

In the end, the result was perhaps not very surprising, given a knowledge of where each candidate was from, what each candidate was known for, how the candidates had campaigned (and how much, and where), how they had fared in previous elections, and what people 'on the street' said about them. The biggest surprise was Ronny Knight's finishing second in the race for the Open seat. Many people saw him as a dark horse. Though he claimed to have a base vote among his wife's kin from Ahus, in Lorengau, where he resided, and among the Mouk people (in Rapatona and Balopa LLGs), most believed that, as a white person, he was without a real base vote. However, it seems that several elders and traditional leaders had chosen to support him. He was well known all over Manus, and was known in several places for helping people in need. People often stressed that as a white man who had grown up in Manus, he knew what it was like to be Manusian because he had shared the same hardships as everyone 
else. Rather than vote for a kinsman who could not be trusted to share the ups and downs of life, many people chose Ronny Knight because he had proven to belong. Being white, he may have been seen by some as being above the wantokism that is widely seen as dominating Papua New Guinea politics - even though some said that Knight, too, protected his own 'boys' when they were in trouble. ${ }^{12}$ People may have been careful about openly stating their support for Knight, due to the expectations of various kin. Several candidates were surprised about their own poor showing, but the 'deceit' of pretending to support the candidate you are 'supposed' to support (due to kinship, exchange obligations, etc.), or at least not revealing your favourite candidate, is not uncommon in Manus (cf. Pokawin and Rooney 1996).

Another unexpected outcome was the poor showing of Simeon Malai, the former provincial administrator, in the contest for the Open seat. However, considering that he had left Manus immediately after quitting his job as provincial administrator, and returned only six months before the election, without the large retrenchment payout he was rumoured to have received, even some of his own kin referred to him as 'the prodigal son'. Malai had worked closely with Pokawin and was in the eyes of many people still closely associated with himwhich may have affected peoples' choice.

Another candidate told me that he felt his own poor result to be a vote-ofno-confidence in him as a leader of his descent group. Several candidates had expected to do better than they did. In part this may have been due to one of the characteristics of Manus electoral politics that Pokawin and Rooney (1996) have labelled the 'deceit of hospitality'. People in villages usually show hospitality towards all visiting candidates (unless of course they are in a direct conflict with the person or his perceived group) and having heard the candidate speak, someone will often say something that will encourage the candidate, simply to make sure that he or she is not disappointed about the meeting. Consequently, several candidates returned from village meetings believing that they had secured votes in that place. Such 'deceit' is practical: offending someone who might later win may cut the community off from government services (see also Pokawin and Rooney 1996:133-134). In addition, people claimed that hospitality was a tradition (kastam), and anyone who took up the challenge of the election deserved respect as a 'bigman'.

12 For comparison with another white person contesting elections in Manus, see Wanek and Wormald (1989). 


\section{The aftermath}

Job Pomat, the winner of the Open seat, as a member of People's National Congress became a minister in the Somare government. Michael Sapau, the winner of the regional seat, joined the National Alliance before the formation of government. There has been some speculation that National Alliance in reality had two candidates. Different stories were circulating about why Sapau and Pokawin ended up contesting the same seat. One was that Sapau, as a financial member of National Alliance, was supposed to have been that party's candidate for the Open seat, but that he switched to the Provincial because of a grudge against Jumogot; another story was that the National Alliance party machinery had decided to endorse Pokawin, forcing Sapau to contest as an independent (see Post-Courier 25 July 2007). The confusion about Sapau's party affiliation, since the Rural Development Party had claimed that he was their candidate, led Jumogot to make an appeal to the court of disputed returns. The appeal was dismissed a few months after the election.

Because LLG elections were not conducted simultaneously with the national election, the terms of the members of the Lapan Assembly ran out immediately after the national election. This led Governor Sapau to appoint seven members to the Lapan Assembly in order to approve a budget for the province. These appointments are reported to have been controversial, since appointed members consequently outnumbered the elected representatives in the assembly. ${ }^{13}$

Despite the complaints and grievances that emerged, the election in Manus was to the best of my knowledge generally fair. There may have been slight irregularities, but these would not have changed the final outcome.

\section{References}

Carrier, J. and Carrier, A., 1989. Wage, Trade, and Exchange. Berkeley: University of California Press.

Dalsgaard, S., 2007. 'Revendiquer sa culture: nouvelle definitions et propriete des pratiques culturelles dans la Province de Manus (Papouasie NouvelleGuinee)', Journal de la Société des Océanistes 125(2):229-236.

Dalsgaard, S. and Otto, T., forthcoming. 'From kastam to kalsa ? Leadership, cultural heritage and modernization in Manus Province, Papua New Guinea', in E. Hviding and K. Rio (eds), Cultural Heritage and Political Innovation: The State and Alternative Social Movements in the Pacific. Wantage: Sean Kingston Publishing. 
Foster, R., 1996. 'State ritual: ethnographic notes on voting in the Namatanai electorate', in Y. Saffu (ed.), The 1992 Papua New Guinea Election: Change and Continuity in Electoral Politics. Political and Social Change Monograph 23. Canberra: Research School of Pacific and Asian Studies, The Australian National University, pp. 144-167.

Gibbs, P., Haley, N. and McLeod, A., 2004. 'Politicking and voting in the highlands: the 2002 Papua New Guinea national elections'. State, Society and Governance in Melanesia Discussion Paper 2004/1. Canberra: State, Society and Governance in Melanesia Program, The Australian National University.

Hughes, C. A. and van der Veur, P. W., 1965. 'The elections: an overview', in D. G. Bettison, C. A. Hughes and P. W. van der Veur (eds), The PapuaNew Guinea Elections 1964. Canberra: The Australian National University, pp. 388-429.

Minol, B. (ed.), 2000. Manus from the Legends to the Year 2000: A History of the People of Manus. Port Moresby: UPNG Press.

Otto, T., 1991. 'The Politics of Tradition in Baluan'. PhD thesis, Research School of Pacific Studies, The Australian National University.

Otto, T., 1992a. 'The Paliau Movement in Manus and the objectification of tradition', History and Anthropology 5(3-4):427-454.

Otto, T., 1992b. 'The ways of kastam: tradition as category and practice in a Manus village', Oceania 62(4):264-283.

Otto, T., 2002. 'Chefs, big men et bureaucrates. Weber et les politiques de la tradition à Baluan (Papouasie-Nouvelle-Guinée)', in C. Hamelin and E. Wittersheim (eds), La Tradition et L'État. Paris: Harmattan, pp.103-129.

Pokawin, S. and Rooney, N., 1996. 'Manus: reign of subtlety over deception of hospitality', in Y. Saffu (ed.), The 1992 Papua New Guinea Election: Change and Continuity in Electoral Politics. Political and Social Change Monograph 23. Canberra: Research School of Pacific and Asian Studies, The Australian National University, pp. 122-143.

Schwartz, T., 1963. 'Systems of areal integration: some considerations based on the Admiralty Islands of northern Melanesia', Anthropological Forum $1(1): 56-97$.

Schwartz, T., 1995. 'Cultural totemism: ethnic identity primitive and modern', in L. Romanucci-Ross and G. De Vos (eds), Ethnic Identity. Creation, Conflict and Accommodation. Walnut Creek: Altamira Press, pp. 48-72. 
Wanek, A. and Wormald, E., 1989. 'Manus: Provincial and Open electorates', in M. Oliver (ed.), Eleksin: The 1987 National Election in Papua New Guinea. Port Moresby: University of Papua New Guinea, pp. 189-207.

\section{Appendix}

Table 27.1: Voting statistics for Manus Open electorate, 2007 election

\begin{tabular}{lrr}
\hline Number of registered voters & 26,918 \\
Total votes cast & 21,314 \\
Informal votes & $679 \quad$ (3.2\% of total ballots cast) \\
Total allowable ballot papers & 20,635 \\
Total ballot papers remaining in count & 11,174 \\
Total votes distributed & 12,639 \\
Exhausted ballot papers & $9,461 \quad$ (45.8\% of allowable ballots) \\
Absolute majority $(50 \%+1)$ & 5,588 \\
\hline
\end{tabular}

Full results for Manus Provincial were not available. Summary results can be found at the end of this book. 
Election 2007: The Shift to Limited Preferential Voting in Papua New Guinea

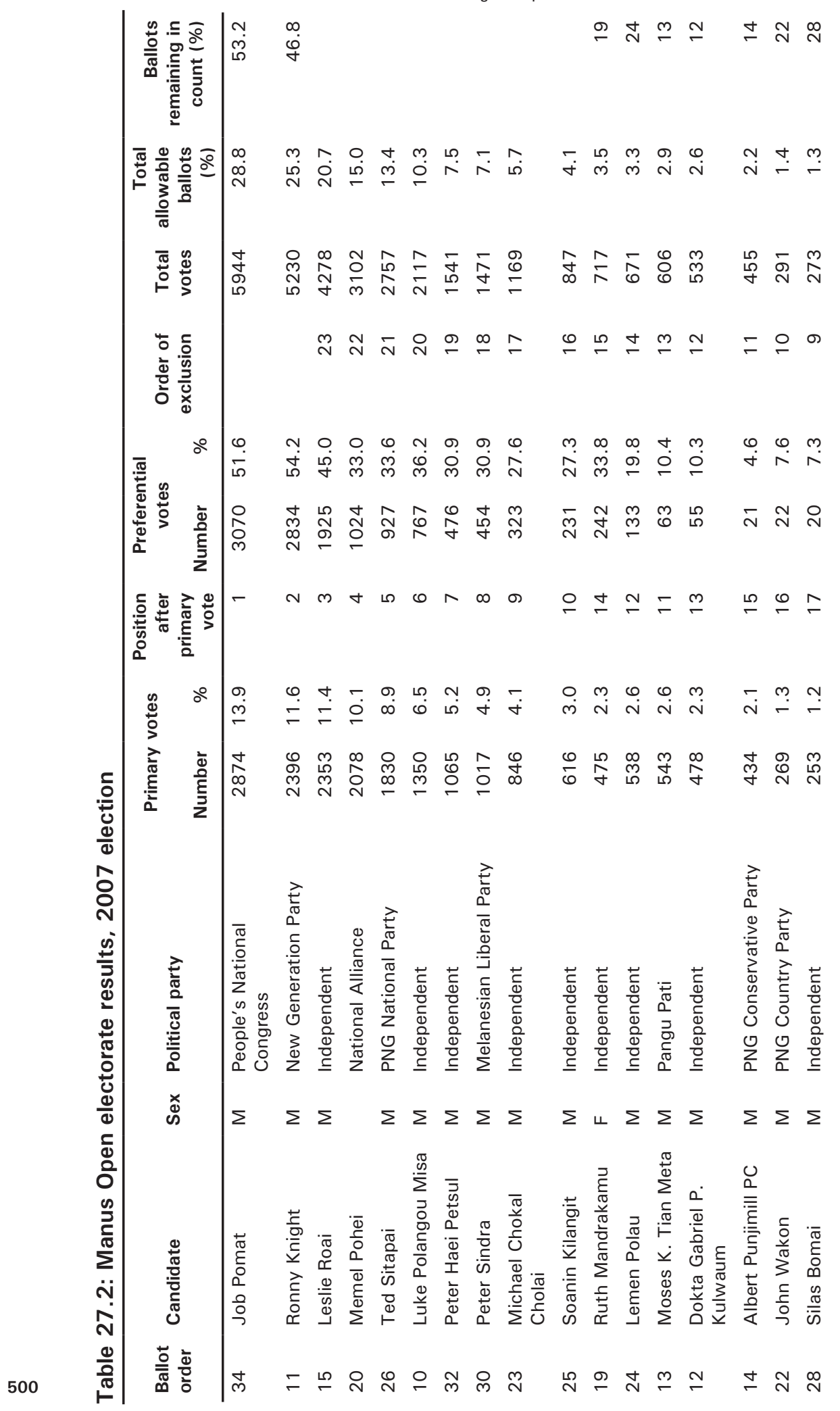


27. Between Eagles and Flying Foxes: Elections for the Manus Provincial and Open Seats

\begin{tabular}{|c|c|c|c|c|c|c|}
\hline 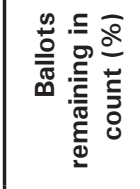 & $\stackrel{\infty}{\sim} \stackrel{\infty}{\sim}$ & $\stackrel{0}{-}$ & $\hat{N}$ & $\stackrel{m}{m}$ & - & $\bar{m}$ \\
\hline 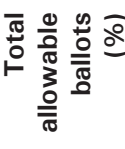 & $\stackrel{m}{\stackrel{n}{-}} \stackrel{-}{-}$ & $\check{r}$ & $\hat{0}$ & $\stackrel{\text { ?ִ }}{\circ}$ & مُ & $\stackrel{+}{+} \quad \stackrel{\circ}{\circ}$ \\
\hline 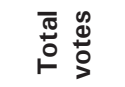 & 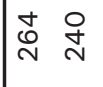 & ลั & 它 & $\stackrel{m}{=}$ & 음 & $\infty \stackrel{\infty}{\curvearrowright}$ \\
\hline 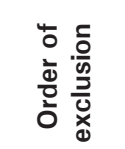 & $\infty \wedge$ & 0 & ما & $\nabla$ & $m$ & $N-$ \\
\hline क̊ & \begin{tabular}{ll}
$\stackrel{N}{*}$ & \multicolumn{1}{c}{} \\
$\sim$ &
\end{tabular} & $\underset{N}{N}$ & $\begin{array}{l}+ \\
\infty\end{array}$ & $\hat{i}$ & $\stackrel{\circ}{\circ}$ & 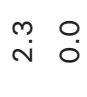 \\
\hline 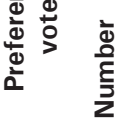 & $\mp \stackrel{\infty}{ }$ & م & $\stackrel{m}{-}$ & $m$ & 0 & $\sim 0$ \\
\hline : & 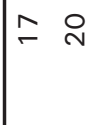 & $\stackrel{\circ}{-}$ & $\bar{N}$ & N & $\stackrel{m}{N}$ & $\stackrel{\sim}{\sim} \stackrel{\llcorner}{N}$ \\
\hline$\stackrel{\infty}{\stackrel{0}{0}}$ & $\stackrel{\sim}{\check{-}}$ & 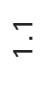 & $\hat{o}$ & $\stackrel{2}{\circ}$ & ?ִ & $\begin{array}{ll}\stackrel{+}{*} & \stackrel{0}{0}\end{array}$ \\
\hline 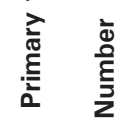 & $\stackrel{\mathscr{N}}{\stackrel{N}{N}} \underset{N}{N}$ & $\stackrel{ \pm}{N}$ & 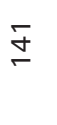 & 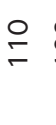 & $\stackrel{8}{\circ}$ & 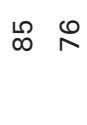 \\
\hline 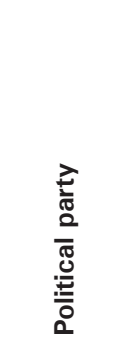 & 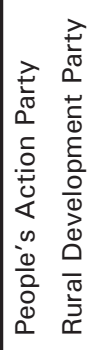 & $\begin{array}{l}\vec{y} \\
\frac{\partial}{\pi} \\
0 \\
\varepsilon \\
0 \\
0 \\
0 \\
\frac{0}{4} \\
0 \\
0 \\
0 \\
\frac{0}{0} \\
0 \\
0 \\
0\end{array}$ & 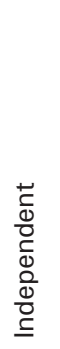 & 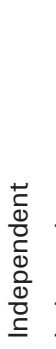 & $\begin{array}{l} \\
\\
+ \\
\vec{c} \\
\frac{0}{0} \\
\frac{0}{0} \\
\frac{0}{0} \\
\underline{0} \\
\underline{\underline{0}}\end{array}$ & 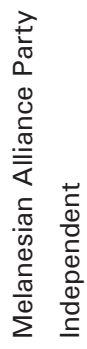 \\
\hline હ & $\Sigma \Sigma$ & $\Sigma$ & $\Sigma$ & $\Sigma$ & $\Sigma$ & $\leftarrow \Sigma$ \\
\hline 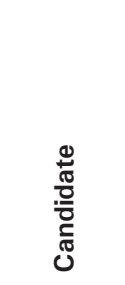 & 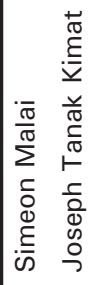 & 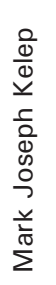 & 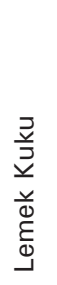 & 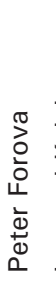 & 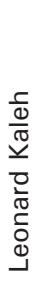 & 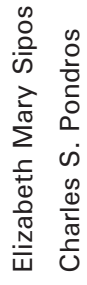 \\
\hline $\begin{array}{l}\text { bै } \\
\overline{\bar{\sigma}} \\
\infty\end{array}$ & $\stackrel{\infty}{\sim} \stackrel{\sim}{\sim}$ & $\stackrel{0}{\square}$ & & $\stackrel{m}{m}$ & & $\bar{m}$ \\
\hline
\end{tabular}

